\title{
CAIX is a predictor of pathological complete response and is associated with higher survival in locally advanced breast cancer submitted to neoadjuvant chemotherapy
}

Wilson Eduardo Furlan Matos Alves ${ }^{1,2^{*}}$ (D), Murilo Bonatelli ${ }^{2}$, Rozany Dufloth ${ }^{3}$, Lígia Maria Kerr ${ }^{3}$, Guilherme Freire Angotti Carrara ${ }^{4}$, Ricardo Filipe Alves da Costa ${ }^{5,6}$, Cristovam Scapulatempo-Neto ${ }^{2}$, Daniel Tiezzi ${ }^{7}$, René Aloísio da Costa Vieira ${ }^{8}$ and Céline Pinheiro ${ }^{2,6}$

\begin{abstract}
Background: Locally advanced breast cancer often undergoes neoadjuvant chemotherapy (NAC), which allows in vivo evaluation of the therapeutic response. The determination of the pathological complete response ( $p C R)$ is one way to evaluate the response to neoadjuvant chemotherapy. However, the rate of pCR differs significantly between molecular subtypes and the cause is not yet determined. Recently, the metabolic reprogramming of cancer cells and its implications for tumor growth and dissemination has gained increasing prominence and could contribute to a better understanding of NAC. Thus, this study proposed to evaluate the expression of metabolismrelated proteins and its association with $\mathrm{PCR}$ and survival rates.

Methods: The expression of monocarboxylate transporters 1 and 4 (MCT1 and MCT4, respectively), cluster of differentiation 147 (CD147), glucose transporter-1 (GLUT1) and carbonic anhydrase IX (CAIX) was analyzed in 196 locally advanced breast cancer samples prior to NAC. The results were associated with clinical-pathological characteristics, occurrence of pCR, disease-free survival (DFS), disease-specific survival (DSS) and overall survival (OS).
\end{abstract}

Results: The occurrence of pCR was higher in the group of patients whith tumors expressing GLUT1 and CAIX than in the group without expression (27.8\% versus $13.1 \%, p=0.030$ and $46.2 \%$ versus $13.5 \%, p=0.007$, respectively). Together with regional lymph nodes staging and mitotic staging, CAIX expression was considered an independent predictor of pCR. In addition, CAIX expression was associated with DFS and DSS ( $p=0.005$ and $p=0.012$, respectively).

Conclusions: CAIX expression was a predictor of pCR and was associated with higher DFS and DSS in locally advanced breast cancer patients subjected to NAC.

Keywords: Breast cancer, CAIX, Glycolytic metabolism, Immunohistochemistry, Neoadjuvant chemotherapy, Pathological complete response

\footnotetext{
* Correspondence: wefma@yahoo.com.br

${ }^{1}$ Nuclear Medicine and Molecular Imaging Department, Barretos Cancer

Hospital - Pio XII Foundation, Rua Antenor Duarte Vilela, N 1331, Barretos,

São Paulo 14784-400, Brazil

${ }^{2}$ Molecular Oncology Research Center, Barretos Cancer Hospital, Barretos, São

Paulo, Brazil

Full list of author information is available at the end of the article
}

(c) The Author(s). 2019 Open Access This article is distributed under the terms of the Creative Commons Attribution 4.0 International License (http://creativecommons.org/licenses/by/4.0/), which permits unrestricted use, distribution, and reproduction in any medium, provided you give appropriate credit to the original author(s) and the source, provide a link to the Creative Commons license, and indicate if changes were made. The Creative Commons Public Domain Dedication waiver (http://creativecommons.org/publicdomain/zero/1.0/) applies to the data made available in this article, unless otherwise stated. 


\section{Background}

Breast cancer $(\mathrm{BC})$ is one of the most prevalent tumors in the world and the most frequent malignancy in women [1]. In the United States of America, only in 2018, approximately 266,000 new cases and close to 41 , 000 deaths are expected due to $\mathrm{BC}$ [2]. In developing countries such as Brazil, the incidence of $\mathrm{BC}$ is lower, but the ratio between mortality and incidence is higher than in developing countries $[3,4]$ and this is associated with a high number of patients diagnosed at a later stage [5]. Neoadjuvant chemotherapy (NAC) is a therapeutic option for locally advanced tumors allowing early treatment of micrometastatic disease, in vivo evaluation of the therapeutic response, increased conservative surgery rate due to tumor shrinkage and prognostic evaluation based on clinical and pathological responses [6].

Defined as the absence of residual invasive carcinoma after NAC in the breast or lymph nodes, the pathological complete response (pCR) is associated with greater overall survival (OS) and disease-free survival (DFS) [7-9]. However, pCR rate differs significantly between molecular subtypes. Although triple-negative tumors are more aggressive with high relapse rates and unfavorable prognosis, they are more chemosensitive with pCR rates ranging from 45 to $56 \%$ [10-12]. Among luminal subtypes, the association between PCR and DFS is observed in luminal B / HER2- but not in luminal A and luminal B / HER2+ [8]. Thus, pCR presents important variations between and within the tumor subgroups and does not seem to be directly related to their clinical characteristics. Thus, it is necessary to know more about other tumor characteristics to better establish the relationship between pathological response and clinical evolution. In this context, information about the metabolic phenotype of cancer cells may provide new insights into factors influencing pathological response and prognosis.

Interest in the metabolic profile of $\mathrm{BC}$ has grown after the introduction of Positron Emission Tomography (PET) in clinical practice, which uses a glucose analog fluorine-18 fluorodeoxyglucose $\left({ }^{18} \mathrm{~F}\right.$-FDG) for evaluation of tumor metabolism [13]. It is known that the main energetic pathway in cancer cells is glycolysis and glucose consumption is much higher in tumors than in normal cells [14]. The preferred use of the glycolytic pathway is related to a series of alterations in tumor cells, which include hypoxia, increased expression of proteins related to glycolytic metabolism and acidification of the extracellular environment [14-17]. All these changes in the tumor microenvironment determine the selection of cells with an acid-resistant hyperglycolytic phenotype [16], associated with increased aggressiveness, growth and dissemination of $\mathrm{BC}$ [18-20].

Some proteins are essential for the effective control of tumor metabolism, including glucose transporter-1 (GLUT1), the main protein responsible for glucose influx
[14]. Proteins related to intracellular $\mathrm{pH}$ control and acidification of the extracellular medium, such as carbonic anhydrase IX (CAIX) and monocarboxylate transporters (MCTs), are essential for cellular metabolism control as well [15]. CAIX is related to $\mathrm{H}^{+}$efflux, acting as a catalyst in a reversible carbon dioxide hydration reaction and its expression has been associated with a worse prognosis in several tumors, including $\mathrm{BC}[14,17]$. The monocarboxylate transporters MCT1 and MCT4, associated with their anchoring protein CD147, have a determinant role in the metabolic reprogramming of cancer cells towards a hyperglycolytic phenotype by promoting the efflux of lactate and pyruvate and, consequently, helping the control of cellular $\mathrm{pH}$, as well as allowing high glycolytic flux [16]. The expression of GLUT1, MCT1, MCT4, and CD147 appears to be associated with increased aggressiveness and lower DFS in BC [19-21].

The aim of this study was to evaluate the expression of MCT1, MCT4, CD147, GLUT1 and CAIX in locally advanced $\mathrm{BC}$ submitted to NAC and their relationship with pCR, DFS, disease-specific survival (DSS) and OS.

\section{Methods}

\section{Patients and clinicopathologic data}

This is a retrospective study approved by the local ethics committee. Clinical and anatomopathological data from 328 female patients admitted consecutively to Barretos Cancer Hospital from 2005 to 2011, with locally advanced breast cancer, clinical stage IIb or III, were used. All patients underwent chemotherapy based on a regimen of doxorubicin plus cyclophosphamide, associated with paclitaxel. Exclusion criteria included: (i) cases whose TMA's tumor samples were not sufficiently representative for evaluation of protein expression; (ii) cases with expression result only for one or two markers; (iii) cases in which clinicopathologic data of interest could not be properly collected from the review of medical records filed at the Barretos Cancer Hospital. After the completion of IHC to evaluate the expression of glycolytic metabolism markers and review of clinicopathological data, the final sample of the study included 196 patients. Of the 132 excluded patients, 19 presented insufficient clinical data on the medical records; 92 did not present representative material in the TMA; and, 21 had expression results for only one or two of the proteins studied.

For all patients, sequential chemotherapy with 4 cycles of doxorubicin $60 \mathrm{mg} / \mathrm{m}^{2}$ and cyclophosphamide 600 $\mathrm{mg} / \mathrm{m}^{2}$ (AC), followed by 4 cycles each 3 weeks or 12 cycles weekly of paclitaxel $175 \mathrm{mg} / \mathrm{m}^{2}(\mathrm{~T})$ was delivered to all patients. Breast surgery and adjuvant radiotherapy were done after NAC. The patients were evaluated every 6 months in the first 5 years of follow-up and annually thereafter. The total follow-up time was considered from 
the date of hospital admission (date of the first consultation) to the date of the last follow-up visit. The diseasefree survival was determined from the date of surgery to the date of the first recurrence (documented by imaging examination) or the date of the last follow-up visit.

The mean age of patients was 49.6 years (range: $29.8-$ 76.0 years) and the mean of the largest tumor diameter was $6.8 \mathrm{~cm}$ (range: $2.0-20.0 \mathrm{~cm}$ ). For synchronous bilateral tumors ( $1 \%$ of cases), we considered the measurement of the largest tumor. At the end of NAC, $75 \%$ of the patients used $4 \mathrm{AC}+4 \mathrm{~T}, 11.7 \%$ of $4 \mathrm{AC}+12 \mathrm{~T}$ and $13.3 \%$ of another chemotherapy regimen. The mean of the largest tumor diameter after NAC was $2.93 \mathrm{~cm}$ (range: $0.0-14.0 \mathrm{~cm}$ ). The surgical treatment was mastectomy in $79.1 \%$ of cases and conservative surgery in the remaining ones. All patients had axillary region surgically approached, with axillary clearance occurring in 98.5\% of cases and sentinel lymph node investigation in the others. All clinicopathologic features used in analysis of this study are summarized in Table 1.

The median follow-up time was 73.9 months (time range, 10.6-125.1 months) and the median DFS was 55.9 months (time range, 1-113 months). Metastatic tumor recurrence was observed in 91 (46.4\%) patients, and locoregional recurrence (isolated or simultaneous to distance recurrence) was observed in 42 (21.4\%). The most compromised sites of distance metastasis were bones (56 cases - 28.6\%) and lungs (40 cases - 20.4\%).

The pathological data related to $\mathrm{BC}$ of each patient before NAC were obtained from biopsy samples and the tumor samples were organized into tissue microarray (TMA). The TMA was made after histological review by a pathologist. Tumor samples were represented in the TMA by $1.5 \mathrm{~mm}$ diameter cores. Several clinicopathologic characteristics were recorded as follow: AJCC TNM stage (7th edition), histological type (invasive no special type -NST - or others), Nottingham histological grade (I - III), tubule formation $(>75 \%, 10-75 \%$ or $<$ $10 \%)$, mitotic rate (1-3), nuclear grade (G1 - G3), necrosis (absent or present), lymphatic invasion (absent or present), Inflammatory infiltrate (absent or present), Ki67 expression $(<14 \%$ or $\geq 14 \%)$, estrogen and progesterone receptors expressions (negative or positive), HER2 overexpression (negative or positive) and immunohistochemical subtype (luminal A, luminal B / HER2-, luminal B / HER2+, HER2 and triple-negative). The luminal A subtype presents estrogen and progesterone receptors expressions and Ki67 < 14\%; the luminal B subtypes have estrogen and progesterone receptors expressions and Ki67 $\geq 14 \%$ with or without HER2 overexpression; the HER2 presents only HER2 overexpression; and triple-negative subtype does not present estrogen and progesterone receptors expressions neither HER2 overexpression.
pCR evaluation was performed after NAC in samples obtained from the analysis of the surgical specimen. The pCR was classified as present or absent based on the criteria of the National Surgical Adjuvant Breast and Bowel Project (NSABP) [22]. The percentage of pCR in this study was $16.3 \%$, with $9.1 \%$ in luminal A, $9.1 \%$ in luminal B / HER2-, 26.1\% in luminal B / HER2+, 25.0\% in HER2 and $19.4 \%$ in triple-negative.

\section{Immunohistochemistry}

The immunohistochemical reactions were performed in the TMA sections according to the avidin-biotinperoxidase complex principle, using the UltraVision ${ }^{\text {Tn }}$ LP Detection System (Thermo Scientific ${ }^{\mathrm{Tm}}$ Lab Vision $^{\mathrm{Tw}}$ ) kits for MCT1 and CD147 proteins and Advance ${ }^{\mathrm{Tm}}$ HRP $\left(D_{a k o}{ }^{\circ}\right)$ for the others, following the indications of the manufacturers and according to the details previously described by the group [23]. First, the TMA sections were deparaffinized and hydrated followed by antigen retrieval with the use of EDTA buffer (1 mM, pH 8) for CD147 or citrate $(0.01 \mathrm{M}, \mathrm{pH} 6)$ to the other proteins in controlled heating $\left(98^{\circ} \mathrm{C}\right)$ for $20 \mathrm{~min}$.

For MCT1 detection, sections were incubated with rabbit polyclonal antibody (AB3538P Chemicon International ${ }^{\circ}$ ), diluted 1:400, overnight, and oral cavity squamous cell carcinoma was used as positive control. MCT4 detection was performed with goat polyclonal antibody (sc-50,329 Santa Cruz Biotechnology ${ }^{\circ}$ ), diluted $1: 200$, for $2 \mathrm{~h}$, and oral squamous cell carcinoma was used as positive control. CD147 reaction was done with mouse monoclonal antibody (clone 1.BB.218, sc-71,038 Santa Cruz Biotechnology $y^{\circ}$, diluted 1:500, overnight, and normal colon was used as positive control. For GLUT1, rabbit polyclonal antibody (ab15309-500 $\mathrm{AbCam} \mathrm{Plc}^{\circ}$ ) was diluted 1:200, incubated for $2 \mathrm{~h}$, and placenta used as positive control. CAIX was detected with rabbit polyclonal antibody (ab15086 $\mathrm{AbCam} \mathrm{Plc}^{\circ}$ ), diluted 1:200, for $2 \mathrm{~h}$, and normal gastric tissue was used as positive control. Finally, slides were counterstained with hematoxylin and permanently mounted.

The IHC reactions were assessed by two observers, who scored the sections semiquantitatively in relation to the positive control as previously described [17, 24]: 0 , $0 \%$ of immunoreactive cells; $1,<5 \%$ of immunoreactive cells; $2,5-50 \%$ of immunoreactive cells; and $3,>50 \%$ of immunoreactive cells. Also, intensity of staining was scored as 0 , negative; 1 , weak; 2 , intermediate; and 3 , strong. Final immunoreactivity score was defined as the sum of both parameters (extent and intensity) and grouped as negative (score 0 and 2) and positive (3-6) $[17,24]$. Discordant results were discussed by the same two observers at a double-head microscope to reach a final score. The two observers analyzed membrane and cytoplasmic expressions of the metabolism-related 
Table 1 Clinicopathologic characteristics of BC samples, before NAC, for all patients included $\left(n=196^{\mathrm{a}}\right.$ )

\begin{tabular}{|c|c|c|c|}
\hline Characteristics & Categories & $\mathrm{n}$ & $\%$ \\
\hline \multirow[t]{4}{*}{ TNM - T } & $\mathrm{T} 1$ & 2 & 1.0 \\
\hline & $\mathrm{T} 2$ & 17 & 8.7 \\
\hline & T3 & 102 & 52.0 \\
\hline & $\mathrm{T} 4$ & 75 & 38.3 \\
\hline \multirow[t]{4}{*}{ TNM - N } & No & 22 & 11.2 \\
\hline & N1 & 116 & 59.2 \\
\hline & N2 & 51 & 26.0 \\
\hline & N3 & 7 & 3.6 \\
\hline TNM - M & Mo & 196 & 100.0 \\
\hline \multirow[t]{2}{*}{ Histological type } & Invasive no special type (NST) & 169 & 86.2 \\
\hline & Others & 27 & 13.8 \\
\hline \multirow[t]{3}{*}{ Nottingham histological grade } & । & 16 & 8.2 \\
\hline & $\|$ & 84 & 42.9 \\
\hline & III & 96 & 49.0 \\
\hline \multirow[t]{3}{*}{ Tubule formation } & $>75 \%$ & 4 & 2.0 \\
\hline & $10-75 \%$ & 16 & 8.2 \\
\hline & $<10 \%$ & 176 & 89.8 \\
\hline \multirow[t]{3}{*}{ Mitotic rate } & 1 & 76 & 38.8 \\
\hline & 2 & 59 & 30.1 \\
\hline & 3 & 61 & 31.1 \\
\hline \multirow[t]{3}{*}{ Nuclear grade } & G1 & 12 & 6.1 \\
\hline & G2 & 50 & 25.5 \\
\hline & G3 & 134 & 68.4 \\
\hline \multirow[t]{2}{*}{ Necrosis } & Absent & 121 & 61.7 \\
\hline & Present & 75 & 38.3 \\
\hline \multirow[t]{2}{*}{ Lymphatic invasion } & Absent & 156 & 80.4 \\
\hline & Present & 38 & 19.6 \\
\hline \multirow[t]{2}{*}{ Inflammatory infiltrate } & Absent & 44 & 22.4 \\
\hline & Present & 152 & 77.6 \\
\hline \multirow[t]{2}{*}{ Ki67 } & $<14 \%$ & 25 & 12.8 \\
\hline & $\geq 14 \%$ & 171 & 87.2 \\
\hline \multirow[t]{2}{*}{ Estrogen receptor } & Negative & 64 & 32.7 \\
\hline & Positive & 132 & 67.3 \\
\hline \multirow[t]{2}{*}{ Progesterone receptor } & Negative & 85 & 43.4 \\
\hline & Positive & 111 & 56.6 \\
\hline \multirow[t]{2}{*}{ HER2 overexpression } & Negative & 129 & 65.8 \\
\hline & Positive & 67 & 34.2 \\
\hline \multirow[t]{5}{*}{ Subtype } & Luminal A & 22 & 11.2 \\
\hline & Luminal B/HER2 - & 77 & 39.3 \\
\hline & Luminal B/HER2 + & 46 & 23.5 \\
\hline & HER2 & 20 & 10.2 \\
\hline & Triple-negative & 31 & 15.8 \\
\hline
\end{tabular}

(a) Excepted at Lymphatic invasion, where $n=194$ 
proteins in all samples. However, due to the functional aspect, only membrane expression was considered in the statistical analysis.

\section{Statistical analysis}

The results obtained were analyzed using the statistical software $\mathrm{IBM}^{\circ}$-SPSS (version 20). All comparisons were examined for statistical significance using Pearson chisquare test $(\mathrm{x} 2)$ or Fisher's exact test, as appropriate. Multivariate logistic regression was performed for variables with $p$-value $<0.20$ at univariate regression.

OS, DSS and DFS curves were plotted using KaplanMeier method. Log-rank test was performed to compare survival curves for all characteristics. The characteristics that showed p-value $<0.20$ at log-rank test were selected for the Cox proportional hazards regression model. For all statistical analyses, a significance level of $5 \%$ (p-value $<0.05)$ was adopted.

\section{Results}

Expression of proteins related to glycolytic metabolism

The membrane and cytoplasmic expressions of metabolism-related proteins can be observed at Fig. 1. Considering only membrane analysis, MCT1, MCT4, CD147, GLUT1 and CAIX expression in the sample was 6.5\% (12/174), 9.4\% (17/163), 2.2\% (4/181), 19\% (36/153) and $7.4 \%(13 / 163)$, respectively.

The association between metabolism-related proteins and clinicopathologic characteristics was also evaluated (Additional file 1: Table S1). For MCT1 expression, there was a statistically significant association with absence of estrogen receptor $(\mathrm{ER})(p=0.042)$ and progesterone receptor (PR) $(p=0.032)$, mitotic rate $3(p=0.038)$ and Nottingham histological grade III $(p=0.001)$. Regarding MCT4 expression, there were statistically significant associations with primary tumor staging $(\mathrm{TNM}-\mathrm{T})(p=0.018)$, regional lymph nodes staging (TNM - N) $(p=0.048)$ and necrosis occurrence $(p=0.019)$. When the association of CD147 with clinical and pathological characteristics was analyzed, there was association with regional lymph nodes staging $(\mathrm{TNM}-\mathrm{N})(p=0.017)$, triple-negative subtype $(p=0.030)$ and absence of PR $(p=0.041)$. GLUT1 expression was a significantly associated with primary tumor staging (TNM $\mathrm{T})(p=0.020)$, regional lymph nodes staging (TNM - N) $(\mathrm{p}=0.001)$, nuclear grade G3 $(p=0.031)$ and presence of necrosis $(p=0.013)$. Regarding CAIX expression, there was association with absence of ER $(\mathrm{p}=0.019)$ and PR $(p=$ $0.011)$, nuclear grade G3 $(p=0.007)$ and presence of necrosis $(p=0.019)$.

\section{Protein expression and clinical and pathological characteristics and their association with $\mathrm{PCR}$}

As observed in Table 2, at univariate analysis, characteristics as age $<50$ years old, advanced regional lymph nodes staging (TNM-N), HER2 overexpression and GLUT1 and CAIX expressions were associated with pCR. At this same analysis, estrogen receptor expression and mitotic rate 3 occurrence also demonstrated a statistic association, however as negative predictors of pCR.

When logistic regression (multivariate analysis) was performed, regional lymph nodes staging (TNM-N), mitotic rate and CAIX expression were considered independent $\mathrm{pCR}$ predictors. It is interesting to note that TNM-N and mitosis rate have reversed their association with pCR and only CAIX expression has remained as independent positive predictor of $\mathrm{pCR}$.

\section{Survival analysis}

The association of proteins related to glycolytic metabolism with DFS, DSS, and OS is observed in Table 3,

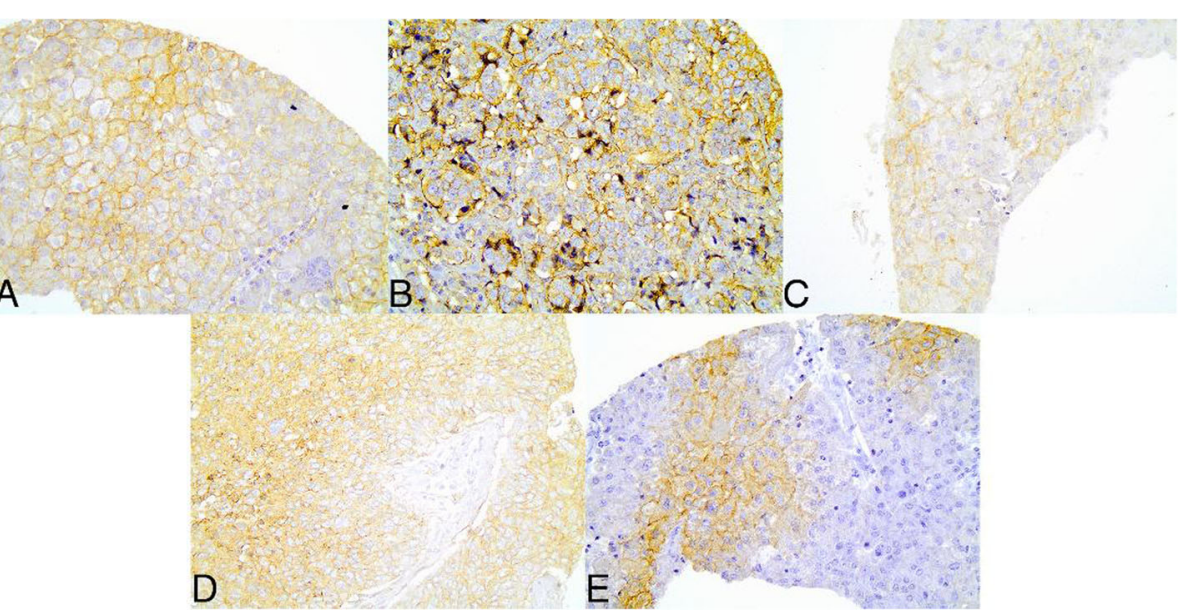

Fig. 1 Representative images of the immunohistochemical findings (membrane and citoplasmatic expressions) for the different metabolismrelated proteins in breast cancer samples. a MCT1; b MCT4; c CD147; d GLUT1; e CAIX 
Table 2 Association of clinicopathologic characteristics and proteins related to glycolytic metabolism with pathological complete response $(p C R)$ - univariate and multivariate analysis

\begin{tabular}{|c|c|c|c|c|c|}
\hline \multirow[t]{2}{*}{ Characteristics } & \multirow[t]{2}{*}{ Categories } & \multicolumn{2}{|l|}{$\underline{\text { Univariate analysis }}$} & \multicolumn{2}{|l|}{ Multivariate analysis } \\
\hline & & Odds Ratio (95\% Cl) & $p$ & Odds Ratio (95\% Cl) & $p$ \\
\hline \multirow[t]{2}{*}{ Age (years) } & $\geq 50$ & Ref & & Ref & \\
\hline & $<50$ & $2.683(1.171-6.149)$ & 0.020 & $2.631(0.856-8.087)$ & 0.091 \\
\hline \multirow[t]{2}{*}{ Histological type } & Invasive NST & Ref & & Ref & \\
\hline & Others & $0.371(0.083-1.650)$ & 0.193 & $0.723(0.114-4.605)$ & 0.731 \\
\hline \multirow[t]{2}{*}{ TNM - T } & $\mathrm{T} 1+\mathrm{T} 2$ & Ref & & - & \\
\hline & $\mathrm{T} 3+\mathrm{T} 4$ & $1.323(0.545-3.211)$ & 0.536 & - & \\
\hline \multirow[t]{2}{*}{ TNM - N } & $\mathrm{NO}+\mathrm{N} 1$ & Ref & & Ref & \\
\hline & $\mathrm{N} 2+\mathrm{N} 3$ & $3.436(1.147-10.293)$ & 0.027 & $0.182(0.038-0.887)$ & 0.035 \\
\hline \multirow[t]{5}{*}{ Subtype } & Luminal A & Ref & & Ref & \\
\hline & Luminal B/HER2 - & $1.000(0.192-5.197)$ & 1.000 & $0.458(0.049-4.311)$ & 0.494 \\
\hline & Luminal B/HER2 + & $3.529(0.716-17.404)$ & 0.121 & $2.029(0.067-61.316)$ & 0.684 \\
\hline & HER2 & $3.333(0.567-19.593)$ & 0.183 & $0.647(0.016-26.726)$ & 0.818 \\
\hline & Triple-negative & $2.400(0.436-13.202)$ & 0.314 & $0.183(0.011-2.926)$ & 0.230 \\
\hline \multirow[t]{2}{*}{ Estrogen receptor } & Negative & Ref & & Ref & \\
\hline & Positive & $0.354(0.164-0.767)$ & 0.008 & $0.254(0.041-1.552)$ & 0.138 \\
\hline \multirow[t]{2}{*}{ Progesterone receptor } & Negative & Ref & & - & \\
\hline & Positive & $1.185(0.554-2.534)$ & 0.662 & - & \\
\hline \multirow[t]{2}{*}{ HER2 overexpression } & Negative & Ref & & Ref & \\
\hline & Positive & $2.584(1.197-5.580)$ & 0.016 & $0.922(0.057-14.873)$ & 0.954 \\
\hline \multirow[t]{2}{*}{ Ki 67} & $<14 \%$ & Ref & & - & \\
\hline & $\geq 14 \%$ & $2.447(0.547-10.940)$ & 0.242 & - & \\
\hline \multirow[t]{2}{*}{ Tubule formation } & $\geq 10 \%$ & Ref & & - & \\
\hline & $<10 \%$ & $1.118(0.308-4.063)$ & 0.866 & - & \\
\hline \multirow[t]{2}{*}{ Mitotic rate } & $1+2$ & Ref & & Ref & \\
\hline & 3 & $0.324(0.149-0.703)$ & 0.004 & 4.899 (1.439-16.673) & 0.011 \\
\hline \multirow[t]{2}{*}{ Nuclear grade } & $\mathrm{G} 1+\mathrm{G} 2$ & Ref & & Ref & \\
\hline & G3 & $1.802(0.734-4.426)$ & 0.199 & $0.598(0.140-2.546)$ & 0.487 \\
\hline \multirow[t]{2}{*}{ Nottingham histological grade } & $\mathrm{G} 1+\mathrm{G} 2$ & Ref & & - & \\
\hline & G3 & $1.651(0.765-3.564)$ & 0.201 & - & \\
\hline \multirow[t]{2}{*}{ Necrosis } & Absent & Ref & & Ref & \\
\hline & Present & $2.071(0.964-4.449)$ & 0.062 & $1.186(0.3335-4.192)$ & 0.792 \\
\hline \multirow[t]{2}{*}{ Inflammatory infiltrate } & Absent & Ref & & Ref & \\
\hline & Present & $2.258(0.747-6.829)$ & 0.149 & $0.740(0.188-2.916)$ & 0.667 \\
\hline \multirow[t]{2}{*}{ Lymphatic invasion } & Absent & Ref & & - & \\
\hline & Present & $0.538(0.177-1.638)$ & 0.275 & - & \\
\hline \multirow[t]{2}{*}{ MCT1 } & Negative & Ref & & - & \\
\hline & Positive & $0.436(0.054-3.509)$ & 0.436 & - & \\
\hline \multirow[t]{2}{*}{ MCT4 } & Negative & Ref & & - & \\
\hline & Positive & $0.736(0.158-3.418)$ & 0.696 & - & \\
\hline \multirow[t]{2}{*}{ CD147 } & Negative & Ref & & - & \\
\hline & Positive & $1.747(0.176-17.387)$ & 0.634 & - & \\
\hline GLUT1 & Negative & Ref & & Ref & \\
\hline
\end{tabular}


Table 2 Association of clinicopathologic characteristics and proteins related to glycolytic metabolism with pathological complete response ( $\mathrm{PCR}$ - - univariate and multivariate analysis (Continued)

\begin{tabular}{|c|c|c|c|c|c|}
\hline \multirow[t]{2}{*}{ Characteristics } & \multirow[t]{2}{*}{ Categories } & \multicolumn{2}{|l|}{ Univariate analysis } & \multicolumn{2}{|l|}{ Multivariate analysis } \\
\hline & & Odds Ratio $(95 \% \mathrm{Cl})$ & $p$ & Odds Ratio (95\% Cl) & $p$ \\
\hline & Positive & $2.558(1.074-6.091)$ & 0.034 & $3.166(0.882-11.360)$ & 0.077 \\
\hline \multirow[t]{2}{*}{ CAIX } & Negative & Ref & & Ref & \\
\hline & Positive & $5.494(1.689-17.866)$ & 0.005 & $6.221(1.148-33.706)$ & 0.034 \\
\hline
\end{tabular}

NST No Special Type, Ref Reference. Significant values are shown in bold

where percentages of patients free of events are showed after 24, 60 and 120 months. Only CAIX expression was associated with DFS and DSS, with $p=0.005$ and $p=$ 0.012 , respectively (Fig. 2). Cox regression was performed and none of the proteins related to glycolytic metabolism was considered an independent predictor of survival (Additional file 2: Table S2).

\section{Discussion}

The metabolic reprogramming of cancer cells and its implications for tumor growth and dissemination has gained increasing prominence and could contribute to a better understanding of NAC response. Some proteins like glucose tranporters and monocarboxilate transporters are essential for metabolic control and have been characterized as predictors of response and prognostic factors. Thus, this study evaluated the expression of MCT1, MCT4, CD147, GLUT1 and CAIX in locally advanced BC submitted to NAC and their relationship with pCR, DFS, DSS and OS. Unexepectedly, CAIX expression has been showed as predictor of $\mathrm{pCR}$ and was associated with higher DFS and DSS in patients with locally advanced breast cancer treated by NAC using AC-T.

The present study evaluated a cohort of patients with breast cancer at stages IIb and III treated with NAC, whose tumor size was greater than $5.0 \mathrm{~cm}$ in most of the cases. Moreover, there was a long follow-up time with a small number of missed patients. In this population, the expression of MCT1, MCT4, and CD147 was lower than that observed by Pinheiro et al. (19.4, 7.3 and $11.0 \%$, respectively) [20]. GLUT1 and CAIX expressions were also lower than the frequencies of 46.0 and $18.0 \%$ seen in the study by Pinheiro et al. [17] and 28.5 and $12.5 \%$ in the study of Vleugel et al. [25]. It should be considered that in Pinheiro et al. studies $[17,20]$ and Vleugel et al. study [25], the percentage of the population with tumors larger than $5 \mathrm{~cm}$ ranged from 9.9 to $17.6 \%$, while in the present study, tumor size was greater than $5.0 \mathrm{~cm}$ in $90.3 \%$ of the cases. In addition, the antibodies and the positivity criteria used by Vleugel et al. are different from those used in the present study [25].

In accordance with previous studies [17, 18, 20, 26], the expression of the metabolism-related proteins was associated with worse prognostic factors. For instance, tumor characteristics related to loss of differentiation and higher growth and probability of dissemination, like histological grade of Nottingham III, mitotic score 3 and nuclear grade G3 were associated with MCT1, GLUT1 and CAIX. In addition, presence of necrosis was associated with MCT4, GLUT1 and CAIX, while lymph node involvement was associated with MCT4, CD147 and GLUT1 expressions. Finally, the lack of ER and PR

Table 3 Percentage of free-events patients over months when associated the expression of proteins related to glycolytic metabolism with survivals (univariate analysis)

\begin{tabular}{|c|c|c|c|c|c|c|c|c|c|c|c|c|c|c|}
\hline \multirow[t]{2}{*}{ Characteristics } & \multirow[t]{2}{*}{ Categories } & \multirow{2}{*}{$\begin{array}{l}\text { Cases } \\
\text { (n) }\end{array}$} & \multicolumn{4}{|l|}{ DFS } & \multicolumn{4}{|l|}{ DSS } & \multicolumn{4}{|l|}{ OS } \\
\hline & & & $24 \mathrm{mo}$ & $60 \mathrm{mo}$ & $120 \mathrm{mo}$ & $p$ & $24 \mathrm{mo}$ & $60 \mathrm{mo}$ & $120 \mathrm{mo}$ & $p$ & $24 \mathrm{mo}$ & $60 \mathrm{mo}$ & 120 mo & $p$ \\
\hline \multirow[t]{2}{*}{ MCT1 } & Negative & 174 & 86.8 & 68.7 & 19.5 & 0.136 & 91.4 & 68.6 & 55.4 & 0.361 & 91.4 & 66.6 & 51.8 & 0.507 \\
\hline & Positive & 12 & 91.7 & 83.3 & 41.7 & & 91.7 & 83.3 & 41.7 & & 91.7 & 83.3 & 31.3 & \\
\hline \multirow[t]{2}{*}{ MCT4 } & Negative & 163 & 85.7 & 66.6 & 22.0 & 0.259 & 90.7 & 68.7 & 49.2 & 0.982 & 89.6 & 66.7 & 45.7 & 0.364 \\
\hline & Positive & 17 & 88.2 & 57.8 & 28.9 & & 88.2 & 63.5 & 63.5 & & 88.2 & 52.9 & 45.4 & \\
\hline \multirow[t]{2}{*}{ CD147 } & Negative & 181 & 86.7 & 66.4 & 20.5 & 0.072 & 90.6 & 68.2 & 48.9 & 0.374 & 90.6 & 67.3 & 45.8 & 0.085 \\
\hline & Positive & 4 & 75.0 & 25.0 & 25.0 & & 75.0 & 50.0 & 50.0 & & 75.0 & 25.0 & 25.0 & \\
\hline \multirow[t]{2}{*}{ GLUT1 } & Negative & 153 & 89.4 & 66.9 & 20.5 & 0.683 & 92.1 & 69.2 & 47.2 & 0.567 & 90.8 & 66.6 & 43.4 & 0.584 \\
\hline & Positive & 36 & 83.3 & 66.7 & 37.7 & & 91.7 & 69.2 & 65.2 & & 91.7 & 66.7 & 58.8 & \\
\hline \multirow[t]{2}{*}{ CAIX } & Negative & 163 & 84.6 & 66.1 & 18.3 & 0.005 & 89.6 & 66.0 & 45.5 & 0.012 & 89.6 & 64.9 & 42.9 & 0.143 \\
\hline & Positive & 13 & 100.0 & 100.0 & 100.0 & & 100.0 & 100.0 & 100.0 & & 92.3 & 84.6 & 75.2 & \\
\hline
\end{tabular}

DFS Disease-free survival, DSS Disease-specific survival, OS Overall survival, mo Months. Significant values are shown in bold 

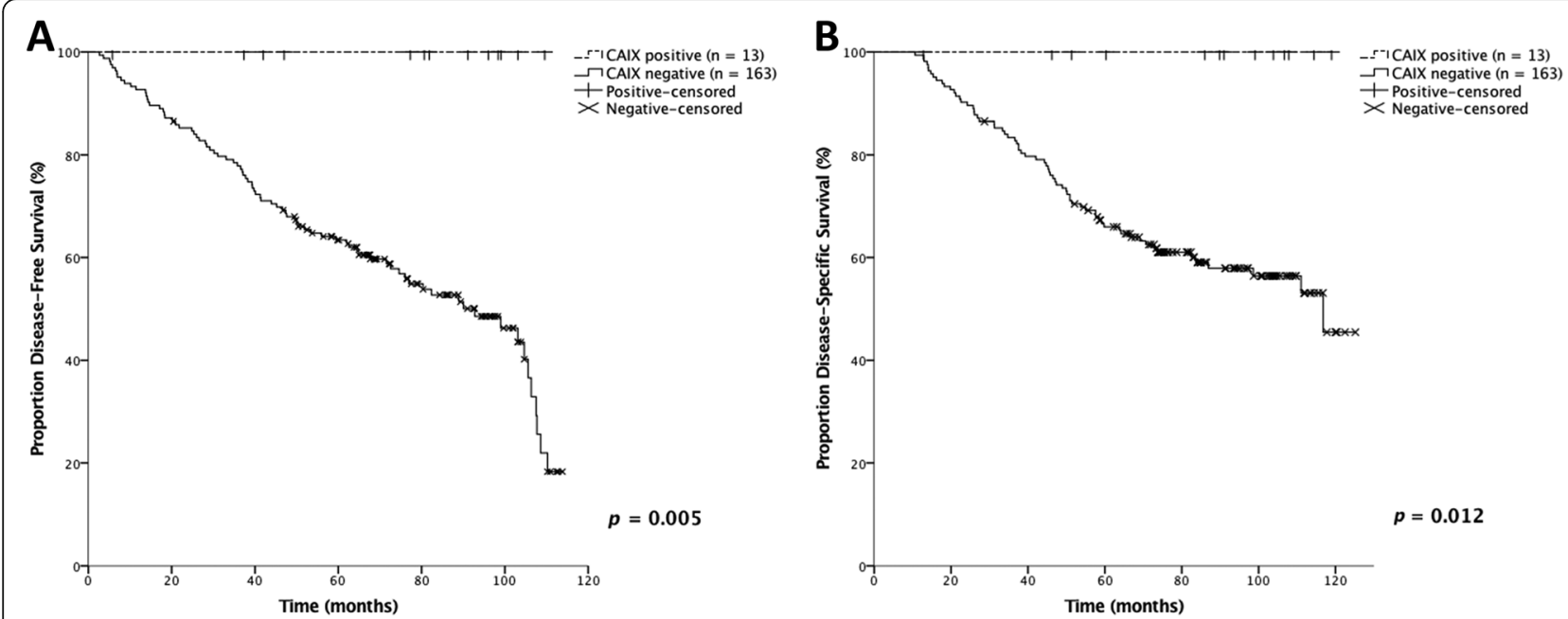

Fig. 2 Disease-free survival curve (a) and disease-specific survival curve (b) of groups with and without CAIX expression. In the curves, DFS and DSS were higher in patients with tumors that expressed CAIX than in those who did not express CAIX (log-rank, $p=0.005$ and $p=0.012$, respectively)

expression was associated with MCT1, CD147, CAIX and GLUT1. The hyperglycolytic and acid-resistant phenotype in undifferentiated cells is responsible for the acidification of the extracellular environment, which, in turn, stimulates tumor progression and dissemination $[15,27-30]$. Also, rapid growth, partly maintained by the hyperglycolytic phenotype, leads to hypoxia and increased necrosis, which also contributes to the metabolic reprogramming towards an hyperglycolytic metabolism, thus creating a cyclic process to stimulate tumor growth and dissemination [15, 27-30]. Therefore, there would be a process of natural selection where tumor cells with characteristics of greater aggressiveness, when manifesting the hyperglycolytic phenotype, would have adaptive advantages for greater proliferation and dissemination.

The percentage of pCR observed (16.3\%) is consistent with data seen in prospective phase II and III clinical trials, ranging from 15 to $30 \%$ and using sequential use of docetaxel to chemotherapy [31,32] or weekly paclitaxel [33]. However, pCR is often related to higher survivals and is more frequently associated with aggressive tumors [7-12, 34-36]. This behaviour has been referred to as the "triple negative paradox phenomenon" [37]. It may be related to the expression of proto-oncogenes and immune response regulatory genes, as well as the lack of an additional therapeutic option (eg hormone therapy), which would allow the rapid evolution of the disease in those cases that do not reach pCR with NAC [37, 38]. In this study, pCR was also associated to aggressive tumors, occurring in $19.4 \%$ of triple negative compared to $9.1 \%$ in luminal A. Our results is in agreement with previous report describing pCR rates ranging from 20.0 to $34.0 \%$ in triple negative, and 0.0 to $7.5 \%$ in luminal A tumors [12]. Additionally, associations were observed between
pCR and age, absence of ER expression, HER2 overexpression, mitotic score, as well as GLUT1 and CAIX expression. In multivariate analysis, only regional lymph nodes staging (TNM - N), mitotic score and CAIX expression were independent predictors of $\mathrm{pCR}$.

To the best of our knowledge, CAIX expression has not been previously described as an independent predictor of pCR. Aomatsu et al. observed that CAIX expression is related to lower $\mathrm{PCR}$ rate and considered this protein a chemoresistance marker [39]. In that study, CAIX expression frequency was $46.0 \%$ [39], whereas in the present study it was only $7.4 \%$. Another difference between the two studies is the frequency of pCR seen in 29.0\% of patients in Aomatsu study versus 16.3\% in the present one [39]. However, the differences in samples' characteristics should be emphasized; while in the present study the sample was comprised of patients with locally advanced tumor treated with AC-T, the Aomatsu et al. study sample consisted of 102 patients with earlystage breast cancer treated with 5-fluorouracil, epirubicin, and cyclophosphamide [39].

Other explanations related to the phenotypic manifestation could explain the unprecedented result of the present study. In a recent study, Euceda et al. [40] evaluated, through magnetic resonance spectroscopy, the metabolic behavior of breast cancer of 122 patients treated with NAC and randomized to sequential use of bevacizumab. Good responders presented an initial metabolic profile related to greater aggressiveness and elevated levels of lactate were observed, which progressively increased throughout the treatment. The authors suggested that patients with tumors with a metabolic profile associated with increased aggressiveness are more likely to benefit from this treatment in terms of reduced 
tumor size, possibly due to a change in their phenotype becoming metabolically non-glycolytic - or related to morphological changes that would block lactate excretion [40]. This would likely alter the tumor microenvironment, reducing extracellular acidity, which would improve the efficacy of chemotherapeutics, classified as weak bases that ionize under low $\mathrm{pH}$ conditions [41]. This context is very similar to that observed in the present study, especially with regard to the greater CAIX expression in pre-treatment tumors from patients who reached pCR after NAC. Even with the expression of a protein responsible for $\mathrm{pH}$ control and promoter of an appropriate microenvironment to tumor growth and proliferation, the expected aggressive phenotype was not able to manifest in the group of patients evaluated in this study, which allowed higher rates of pCR, contrary to the initial expectations.

In line with the association with pCR, CAIX expression was also associated with higher DFS and DSS. These findings were also not previously described, and go against previous studies showing CAIX as a poor prognostic factor [17, 39, 42, 43]. Generali et al. demonstrated women with breast cancer treated with epirubicin and tamoxifen had lower DFS and OS when expressing CAIX [42]. Similarly, Pinheiro et al. observed that CAIX expression was associated with an increased risk of relapse [17]. In the study by Aomatsu et al., in which CAIX expression was evaluated in breast cancer tumor samples before and after NAC, the presence of the protein was prognostic of lower DFS in both situations [39]. As a counterpoint, it is important to cite two studies. In the first one, Ivanova et al. evaluated breast cancer samples of 3455 patients and observed high expression of CAIX mRNA was associated with lower DFS in basal-like and triple negative subtypes and lower OS in luminal B, but not in luminal A and HER2 + [43]. On the other, Chen et al. evaluated the expression of CAIX and CAXII mRNA, enzymes with the same catalytic function, but with related different prognostics predictions (CAIX related to worse and CAXII to good prognosis) [44, 45]. Chen et al. observed high expression of CAIX mRNA was associated with increased survival in the luminal subtype while CAXII mRNA expression was linked to reduced survival in basal and HER2 positive breast cancer [44]. Furthermore, they suggest that CA enzymes could have their functions regulated by changes in the $\mathrm{pH}$ of the tumoral microenvironment [44]. Thus, we can assume that in our study, the conditions of the tumor microenvironment (related to the large tumor size and NAC based on AC-T) may have determined CAIX functional alterations and, consequently, may have been associated with pCR and higher survival. Moreover, in the samples evaluated in our study, the low CAIX expression could be compensated by a higher CAXII expression, unfortunately not evaluated by us. It should be noted the lack of correlation of triple-negative cases with pCR rates in the multivariate analysis. We consider, however, that this finding is strictly related to statistical power. Due to the number of included variables, the final sample size in this analysis was substantially reduced, probably determining this lack of correlation. In addition, among the triple-negative cases that demonstrated pCR, only one of them had CAIX expression. Given these data, we can state that there is no strong correlation between CAIX and $\mathrm{pCR}$ expression between triple-negative tumors, even with the result found in the multivariate analysis.

Since the biological material used in TMA construction is dated from 2005 to 2011, its quality should be considered as a limitation of this study. Although all the samples come from the same service, differences in the techniques of fixing and preserving the material should be considered, which could contribute to the reduction of antigenicity, decrease in the sensitivity of the IHC reaction and, of course, lower detection of protein expression [46, 47]. It is also worth noting that the TMA blocks used in the present study were composed of single samples from each patient and, as already mentioned, there were a considerable number of cases excluded by the lack of tumor representativeness.

\section{Conclusion}

In this study, we describe for the first time CAIX expression as a predictor of $\mathrm{pCR}$ and its association with higher DFS and DSS in patients with locally advanced breast cancer treated by NAC using AC-T. Considering the size of the cohort and the long follow-up time, we believe these results give an important contribution to the knowledge about the participation of glycolytic metabolism to breast cancer response to chemotherapy. New studies evaluating other metabolic parameters such as expression of additional metabolism-related proteins, levels of metabolic byproducts and modifications in metabolism-related genes, could better clarify how the metabolic adaptations of cancer cells may be implicated in tumor behavior against certain therapies, as well as determine prognostic markers and new therapeutic targets within an ideal of personalized medicine.

\section{Supplementary information}

Supplementary information accompanies this paper at https://doi.org/10. 1186/s12885-019-6353-2.

Additional file 1: Table S1. Association between metabolism-related proteins expression and clinicopathologic characteristics. Table showing the association between metabolism-related proteins expression and clinicopathologic characteristics.

Additional file 2: Table S2. Association of clinicopathologic characteristics and proteins related to glycolytic metabolism with DFS, DSS and OS after NAC - Cox proportional hazards regression model. Table showing the association between clinicopathologic characteristics and proteins related to glycolytic metabolism with DFS, DSS and OS after NAC. 


\section{Abbreviations}

AC: Doxorubicin and cyclophosphamide; BC: Breast cancer; CAIX: Carbonic anhydrase IX; DFS: Disease-free survival; DSS: Disease-specific survival; GLUT1: Glucose transporter-1; MCT: Monocarboxylate transporters; NAC: Neoadjuvant chemotherapy; NSABP: National Surgical Adjuvant Breast and Bowel Project; OS: Overall survival; pCR: Pathological complete response; T: Paclitaxel; TMA: Tissue microarray

\section{Acknowledgments}

Not applicable.

\section{Authors' contributions}

WEFMA performed immunohistochemical reactions and statistical analysis, in addition to writing the manuscript. MB performed immunohistochemical reactions. $\mathrm{RD}, \mathrm{LK}$ and $\mathrm{CSN}$ analyzed histological sections and performed the immunohistochemical evaluations. GC and RV performed clinical and pathological data collection. CP, RV, WEFMA, RD and DT aided in the study design. RFAC contributed in the statistical analysis. CP and RV contributed in the discussion of the results and organization of the manuscript. All authors read and approved the manuscript.

\section{Funding}

No funding was obtained for this study.

\section{Availability of data and materials}

The datasets used and/or analyzed during the current study are available from the corresponding author on reasonable request.

\section{Ethics approval and consent to participate}

The study was conducted in accordance with all national and international ethical standards for human research. All study procedures were approved by the Institutional Ethics Committee of the Pio XII Foundation - Barretos Cancer Hospital (approval number 1.604.347). All patients included in the study signed a consent form allowing the use of the informations and biological materials.

\section{Consent for publication}

Not applicable.

\section{Competing interests}

The authors declare that they have no competing interests.

\section{Author details}

${ }^{1}$ Nuclear Medicine and Molecular Imaging Department, Barretos Cancer Hospital - Pio XII Foundation, Rua Antenor Duarte Vilela, N 1331, Barretos, São Paulo 14784-400, Brazil. ${ }^{2}$ Molecular Oncology Research Center, Barretos Cancer Hospital, Barretos, São Paulo, Brazil. ${ }^{3}$ Pathology Department, Barretos Cancer Hospital, Barretos, São Paulo, Brazil. ${ }^{4}$ Surgery Department, Federal University of Triangulo Mineiro, Uberaba, Minas Gerais, Brazil. ${ }^{5}$ Research and Teaching Institute, Barretos Cancer Hospital, Barretos, São Paulo, Brazil. ${ }^{6}$ Barretos School of Health Sciences Dr. Paulo Prata - FACISB, Barretos, São Paulo, Brazil. ${ }^{7}$ Department of Gynecology and Obstetrics - Breast Disease Division, Faculty of Medicine of Ribeirão Preto, University of São Paulo, Ribreirão Preto, São Paulo, Brazil. ${ }^{8}$ Department of Mastology and Breast Reconstruction, Barretos Cancer Hospital, Barretos, São Paulo, Brazil.

Received: 11 June 2019 Accepted: 11 November 2019

Published online: 03 December 2019

\section{References}

1. Fitzmaurice C, Dicker D, Pain A, Hamavid H, Moradi-Lakeh M, Maclntyre MF, Allen C, Hansen G, Woodbrook R, Wolfe C. The global burden of cancer 2013. JAMA Oncol. 2015;1(4):505-27.

2. Siegel RL, Miller KD, Jemal A. Cancer statistics, 2018. CA Cancer J Clin. 2018; 68(1):7-30.

3. DeSantis CE, Bray F, Ferlay J, Lortet-Tieulent J, Anderson BO, Jemal A. International variation in female breast cancer incidence and mortality rates. Cancer Epidemiol Prev. 2015;24(10):1495-506.

4. Parkin DM, Bray F, Ferlay J, Pisani P. Global cancer statistics, 2002. CA Cancer J Clin. 2005;55(2):74-108.
5. Tiezzi DG. Rastreamento do câncer de mama no Brasil: ainda há tempo para refletirmos. CEP. 2013;14049:900.

6. Holmes D, Colfry A, Czerniecki B, Dickson-Witmer D, Espinel CF, Feldman E, Gallagher K, Greenup R, Herrmann V, Kuerer H. Performance and practice guideline for the use of Neoadjuvant systemic therapy in the Management of Breast Cancer. Ann Surg Oncol. 2015;22(10):3184-90.

7. Guarneri V, Broglio K, Kau S-W, Cristofanilli M, Buzdar AU, Valero V, Buchholz T, Meric F, Middleton L, Hortobagyi GN. Prognostic value of pathologic complete response after primary chemotherapy in relation to hormone receptor status and other factors. J Clin Oncol. 2006;24(7):1037-44.

8. von Minckwitz G, Untch M, Blohmer J-U, Costa SD, Eidtmann H, Fasching PA, Gerber B, Eiermann W, Hilfrich J, Huober J. Definition and impact of pathologic complete response on prognosis after neoadjuvant chemotherapy in various intrinsic breast cancer subtypes. J Clin Oncol. 2012;30:1796-804.

9. Yoshioka T, Hosoda M, Yamamoto M, Taguchi K, Hatanaka KC, Takakuwa E, Hatanaka Y, Matsuno Y, Yamashita H. Prognostic significance of pathologic complete response and Ki67 expression after neoadjuvant chemotherapy in breast cancer. Breast Cancer. 2013;22(2):185-91.

10. de Ronde JJ, Hannemann J, Halfwerk H, Mulder L, Straver ME, Peeters M-JTV, Wesseling J, van de Vijver M, Wessels LF, Rodenhuis S. Concordance of clinical and molecular breast cancer subtyping in the context of preoperative chemotherapy response. Breast Cancer Res Treat. 2010;119(1):119-26.

11. Krijgsman O, Roepman P, Zwart W, Carroll JS, Tian S, de Snoo FA, Bender RA, Bernards R, Glas AM. A diagnostic gene profile for molecular subtyping of breast cancer associated with treatment response. Breast Cancer Res Treat. 2012;133(1):37-47.

12. Wang-Lopez Q, Chalabi N, Abrial C, Radosevic-Robin N, Durando X, MouretReynier M-A, Benmammar K-E, Kullab S, Bahadoor M, Chollet P. Can pathologic complete response ( $\mathrm{pCR}$ ) be used as a surrogate marker of survival after neoadjuvant therapy for breast cancer? Crit Rev Oncol Hematol. 2015;95(1):88-104.

13. Basu S, Hess S, Braad P-EN, Olsen BB, Inglev S, Høilund-Carlsen PF. The basic principles of FDG-PET/CT imaging. PET Clinics. 2014;9(4):355-70.

14. Rademakers SE, Lok J, van der Kogel AJ, Bussink J, Kaanders JH. Metabolic markers in relation to hypoxia; staining patterns and colocalization of pimonidazole, HIF-1a, CAIX, LDH-5, GLUT-1, MCT1 and MCT4. BMC Cancer. 2011;11(1):167.

15. Chiche J, Brahimi-Horn MC, Pouysségur J. Tumour hypoxia induces a metabolic shift causing acidosis: a common feature in cancer. J Cell Mol Med. 2010;14(4):771-94.

16. Pinheiro C, Longatto-Filho A, Azevedo-Silva J, Casal M, Schmitt FC, Baltazar F. Role of monocarboxylate transporters in human cancers: state of the art. J Bioenerg Biomembr. 2012;44(1):127-39.

17. Pinheiro C, Sousa B, Albergaria A, Paredes J, Dufloth R, Vieira D, Schmitt F, Baltazar F. GLUT1 and CAIX expression profiles in breast cancer correlate with adverse prognostic factors and MCT1 overexpression. Histol Histopathol. 2011;26(10):1279-86.

18. Baenke F, Dubuis S, Brault C, Weigelt B, Dankworth B, Griffiths B, Jiang M, Mackay A, Saunders B, Spencer-Dene B. Functional screening identifies MCT4 as a key regulator of breast cancer cell metabolism and survival. J Pathol. 2015:237(2):152-65.

19. Doyen J, Trastour C, Ettore F, Peyrottes I, Toussant N, Gal J, Ilc K, Roux D, Parks S, Ferrero J. Expression of the hypoxia-inducible monocarboxylate transporter MCT4 is increased in triple negative breast cancer and correlates independently with clinical outcome. Biochem Biophys Res Commun. 2014; 451(1):54-61.

20. Pinheiro C, Albergaria A, Paredes J, Sousa B, Dufloth R, Vieira D, Schmitt F, Baltazar F. Monocarboxylate transporter 1 is up-regulated in basal-like breast carcinoma. Histopathology. 2010;56(7):860-7.

21. Kang SS, Chun YK, Hur MH, Lee HK, Kim YJ, Hong SR, Lee JH, Lee SG, Park YK. Clinical significance of glucose transporter 1 (GLUT1) expression in human breast carcinoma. Jpn J Cancer Res. 2002;93(10):1123-8.

22. Bear HD, Anderson S, Smith RE, Geyer CE Jr, Mamounas EP, Fisher B, Brown AM, Robidoux A, Margolese R, Kahlenberg MS. Sequential preoperative or postoperative docetaxel added to preoperative doxorubicin plus cyclophosphamide for operable breast cancer: National Surgical Adjuvant Breast and bowel project protocol B-27. J Clin Oncol. 2006;24(13):2019-27.

23. Pinheiro C, Granja S, Longatto-Filho A, Faria AM, Fragoso M, Lovisolo SM, Lerário AM, Almeida MQ, Baltazar F, Zerbini M. Metabolic reprogramming: a new relevant pathway in adult adrenocortical tumors. Oncotarget. 2015; 6(42):44403-21. 
24. Pinheiro C, Longatto-Filho A, Scapulatempo C, Ferreira L, Martins S, Pellerin L, Rodrigues M, Alves VA, Schmitt F, Baltazar F. Increased expression of monocarboxylate transporters 1, 2, and 4 in colorectal carcinomas. Virchows Arch. 2008;452(2):139-46

25. Vleugel M, Greijer A, Shvarts A, Van Der Groep P, Van Berkel M, Aarbodem Y,

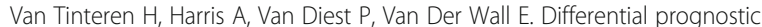
impact of hypoxia induced and diffuse HIF-1a expression in invasive breast cancer. J Clin Pathol. 2005;58(2):172-7.

26. Kim HM, Jung WH, Koo JS. Site-specific metabolic phenotypes in metastatic breast cancer. J Transl Med. 2014;12(1):1-17.

27. Baltazar F, Pinheiro C, Santos FM, Silva JA, Queirós O, Preto A, Casal M. Monocarboxylate transporters as targets and mediators in cancer therapy response. Histol Histopathol. 2014;29(12):1511-24.

28. Gatenby RA, Gillies RJ. Why do cancers have high aerobic glycolysis? Nat Rev Cancer. 2004;4(11):891.

29. Li X, Yu X, Dai D, Song X, Xu W. The altered glucose metabolism in tumor and a tumor acidic microenvironment associated with extracellular matrix metalloproteinase inducer and monocarboxylate transporters. Oncotarget. 2016;7(17):23141.

30. San-Millán I, Brooks GA. Reexamining cancer metabolism: lactate production for carcinogenesis could be the purpose and explanation of the Warburg effect. Carcinogenesis. 2017;38(2):119-33.

31. Bear HD, Anderson S, Brown A, Smith R, Mamounas EP, Fisher B, Margolese $\mathrm{R}$, Theoret $\mathrm{H}$, Soran A, Wickerham DL. The effect on tumor response of adding sequential preoperative docetaxel to preoperative doxorubicin and cyclophosphamide: preliminary results from National Surgical Adjuvant Breast and bowel project protocol B-27. J Clin Oncol. 2003;21(22):4165-74.

32. Smith IC, Heys SD, Hutcheon AW, Miller ID, Payne S, Gilbert FJ, Ah-See AK, Eremin O, Walker LG, Sarkar TK. Neoadjuvant chemotherapy in breast cancer: significantly enhanced response with docetaxel. J Clin Oncol. 2002; 20(6):1456-66.

33. Green MC, Buzdar AU, Smith T, Ibrahim NK, Valero V, Rosales MF, Cristofanilli M, Booser DJ, Pusztai L, Rivera E. Weekly paclitaxel improves pathologic complete remission in operable breast cancer when compared with paclitaxel once every 3 weeks. J Clin Oncol. 2005;23(25):5983-92.

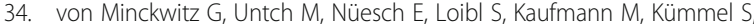
Fasching PA, Eiermann W, Blohmer J-U, Costa SD. Impact of treatment characteristics on response of different breast cancer phenotypes: pooled analysis of the German neo-adjuvant chemotherapy trials. Breast Cancer Res Treat. 2011;125(1):145-56.

35. Yang Y, Im S-A, Keam B, Lee KH, Kim TY, Suh KJ, Ryu HS, Moon H-G, Han SW, Oh DY. Prognostic impact of AJCC response criteria for neoadjuvant chemotherapy in stage II/II breast cancer patients: breast cancer subtype analyses. BMC Cancer. 2016;16(1):515.

36. Bhargava R, Beriwal S, Dabbs DJ, Ozbek U, Soran A, Johnson RR, Brufsky AM, Lembersky BC, Ahrendt GM. Immunohistochemical surrogate markers of breast cancer molecular classes predicts response to neoadjuvant chemotherapy. Cancer. 2010;116(6):1431-9.

37. Carey LA, Dees EC, Sawyer L, Gatti L, Moore DT, Collichio F, Ollila DW, Sartor Cl, Graham ML, Perou CM. The triple negative paradox: primary tumor chemosensitivity of breast cancer subtypes. Clin Cancer Res. 2007;13(8):2329-34.

38. Gianni L, Zambetti M, Clark K, Baker J, Cronin M, Wu J, Mariani G, Rodriguez J, Carcangiu M, Watson D. Gene expression profiles in paraffin-embedded core biopsy tissue predict response to chemotherapy in women with locally advanced breast cancer. J Clin Oncol. 2005;23(29):7265-77.

39. Aomatsu N, Yashiro M, Kashiwagi S, Kawajiri H, Takashima T, Ohsawa M, Wakasa K, Hirakawa K. Carbonic anhydrase 9 is associated with chemosensitivity and prognosis in breast cancer patients treated with taxane and anthracycline. BMC Cancer. 2014;14(1):400.

40. Euceda LR, Haukaas TH, Giskeødegård GF, Vettukattil R, Engel J, Silwal-Pandit L, Lundgren S, Borgen E, Garred $\varnothing$, Postma G. Evaluation of metabolomic changes during neoadjuvant chemotherapy combined with bevacizumab in breast cancer using MR spectroscopy. Metabolomics. 2017;13(4):37.

41. Betof A, Rabbani Z, Hardee M, Kim S, Broadwater G, Bentley R, Snyder S, Vujaskovic Z, Oosterwijk E, Harris L. Carbonic anhydrase IX is a predictive marker of doxorubicin resistance in early-stage breast cancer independent of HER2 and TOP2A amplification. Br J Cancer. 2012;106(5):916.

42. Generali D, Fox SB, Berruti A, Brizzi MP, Campo L, Bonardi S, Wigfield SM, Bruzzi P, Bersiga A, Allevi G. Role of carbonic anhydrase IX expression in prediction of the efficacy and outcome of primary epirubicin/tamoxifen therapy for breast cancer. Endocr Relat Cancer. 2006;13(3):921-30.
43. Ivanova L, Zandberga E, Siliņa K, Kalniņa Z, Ābols A, Endzeliņš E, Vendina I, Romanchikova N, Hegmane A, Trapencieris P. Prognostic relevance of carbonic anhydrase IX expression is distinct in various subtypes of breast cancer and its silencing suppresses self-renewal capacity of breast cancer cells. Cancer Chemother Pharmacol. 2015;75(2):235-46.

44. Chen Z, Ai L, Mboge MY, Tu C, McKenna R, Brown KD, Heldermon CD, SCJPo F. Differential expression and function of CAIX and CAXII in breast cancer: a comparison between tumorgraft models and cells. PLoS One. 2018;13(7):e0199476.

45. Watson P, Chia S, Wykoff CC, Han C, Leek R, Sly W, Gatter K, Ratcliffe P, AJBjoc $\mathrm{H}$. Carbonic anhydrase XII is a marker of good prognosis in invasive breast carcinoma. Br J Cancer. 2003;88(7):1065.

46. O'hurley G, Sjöstedt E, Rahman A, Li B, Kampf C, Pontén F, Gallagher WM, Lindskog C. Garbage in, garbage out: a critical evaluation of strategies used for validation of immunohistochemical biomarkers. Mol Oncol. 2014:8(4): 783-98.

47. Pinder SE, Brown JP, Gillett C, Purdie CA, Speirs V, Thompson AM, Shaaban AM, Group TSotNBCS. The manufacture and assessment of tissue microarrays: suggestions and criteria for analysis, with breast cancer as an example. J Clin Pathol. 2012;66(3):169-77 jclinpath-2012-201091.

\section{Publisher's Note}

Springer Nature remains neutral with regard to jurisdictional claims in published maps and institutional affiliations.
Ready to submit your research? Choose BMC and benefit from:

- fast, convenient online submission

- thorough peer review by experienced researchers in your field

- rapid publication on acceptance

- support for research data, including large and complex data types

- gold Open Access which fosters wider collaboration and increased citations

- maximum visibility for your research: over $100 \mathrm{M}$ website views per year

At BMC, research is always in progress.

Learn more biomedcentral.com/submissions 